\title{
Application of organizational and technological modeling approaches in the construction of buildings with green roofs
}

\author{
Elena Korol $^{1 *}$, Natalia Shushunova ${ }^{1}$ \\ ${ }^{1}$ Moscow State University of Civil Engineering, Yaroslavskoye Shosse, 26, Moscow, 129337, Russia
}

\begin{abstract}
The predominance of green spaces on the coatings of buildings and structures contributes to the formation and development of a new urban space, improves the environment, reducing greenhouse gas emissions into the atmosphere. The aim of the research is to study the various types of greening systems form a variable base of organizational and technological modelling, which allow to adopt the rational organizational and technological decisions in the construction. The research methodology and research methods are based on the theory and practice of constructing organizational and technological models and methods of rational planning in construction, decision theory, expert assessments, and comparison methods. As the results of streamlining the technological processes and operations of the roofing device with modular greening systems, the organizational and technological sequence of the roofing device with the modular greening system is formed. Application of the approaches of organizational-technological modeling in the construction of buildings with green roofs will allow verification with a limited set of experimental data.
\end{abstract}

\section{Introduction}

The studies of the technological parameters of the device of operated roofs with various types of greening systems form a variable base of organizational and technological modeling and allow the adoption of rational organizational and technological decisions in this area. To assess compliance with the principles of green construction in Russia and foreign countries, existing systems have been developed that provide certification of residential and public buildings.

The national Russian standards in the green construction and energy-efficient building materials include the following standards: GOST R 51387-99 "Energy conservation. Normative and methodological support. The main provisions"; GOST 28329-89 "Gardening of cities"; GOST R 51541-99 Energy Saving. Energy efficiency. Composition of indicators", GOST R 54964-2012. "Conformity assessment. Environmental requirements for real estate". The following foreign standardization systems are used in the field of green building technologies: the BREEAM system developed by the BreGlobal Institute and the

*Corresponding author: professorkorol@mail.ru 
American LEED system developed by the American Green Building Council. Developed by the German Society for Landscape Research, Development and Construction "Guidelines for the Planning, Implementation and Maintenance of Green Roofing" (FLL Guide) reflects the principles of modern green roof technology systems. This manual cannot replace modern American standards, but it is a reliable technical regulation tool based on the experience of building about 1 billion square meters of roofing of buildings with greening systems.

\section{Methodology}

The studies were carried out using the methodology of a systematic approach to the scientific problem of studying in relation to roofing systems with greening systems based on the selection of rational parameters of technological processes. The research methodology and research methods are based on the theory and practice of constructing organizational and technological models and methods of rational planning in construction, decision theory, expert assessments, and comparison methods.

\subsection{The principles of green building construction}

Among the various technologies of green construction, the constructive and technological green roof and green wall systems are most popular (Figure 1). Technological revamping of materials, technological solutions and skills since recent times had primed and popularized green roof applications. The principles of green building construction connected with the growing trend in the construction of buildings with elements of integrated greening and the need to update the regulatory and technical base in this area based on the results of scientific research.

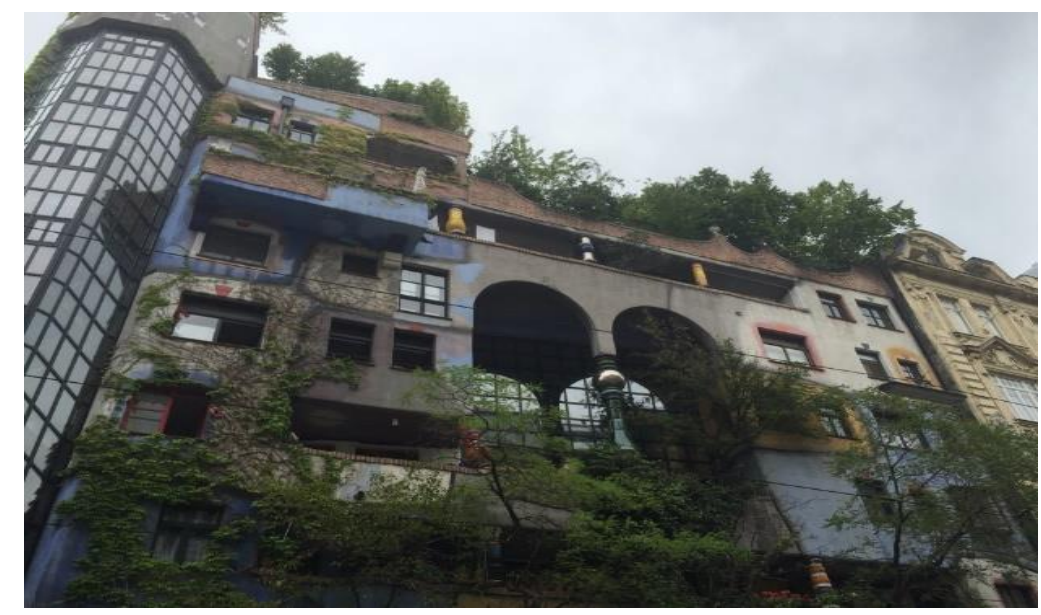

Fig. 1. Green roof and green wall systems of the residential building in Austria

It is important to note that among the numerous studies carried out in the field of technology and the organization of construction work in the framework of published scientific works, questions on the installation of roofing with greening systems have not been sufficiently studied. The effects of substrate depth on plant community, the diffusion of green technologies under uncertainties, the thermal performance evaluation of green roof system and some problems of green roof system have been investigated in the recent articles [1-6]. There is a need to develop new structural and technical solutions and to study 
the installation method and technology for erecting roofing, which would allow rational use of the potential of erection of roofing coatings with greening systems.

\subsection{The solution of installing modular green roof system}

The solution of a roofing device with a modular green roof system should be highlighted. When installing modular green roof system, support elements on a sloping roof are used. In these systems, the main element is the module: a tray with a polygonal shape or with a rounded surface. The trays are quickly and reliably connected into a single coating, forming a "carpet". Such a modular system can be installed on a roof with a slope not exceeding $20 \%$. The mobility and collapsible nature of the roof structure with a modular greening system is the main advantage for the installation of roof coverings in adverse climatic conditions (in the cold season). Creating a roofing with a modular greening system is a fundamentally improved system for constructing roofs with green spaces, including modules adapted for installation on a terrace coating or other surface of an operating coating. Special shaped positioning, allows to use an effective system of drainage from the roof or surface of a terrace coating. Structurally, the modules are installed with the possibility of separation and are connected with snap-on elements, which ensures the effectiveness of repair measures of the roof structure by simply removing the necessary elements.

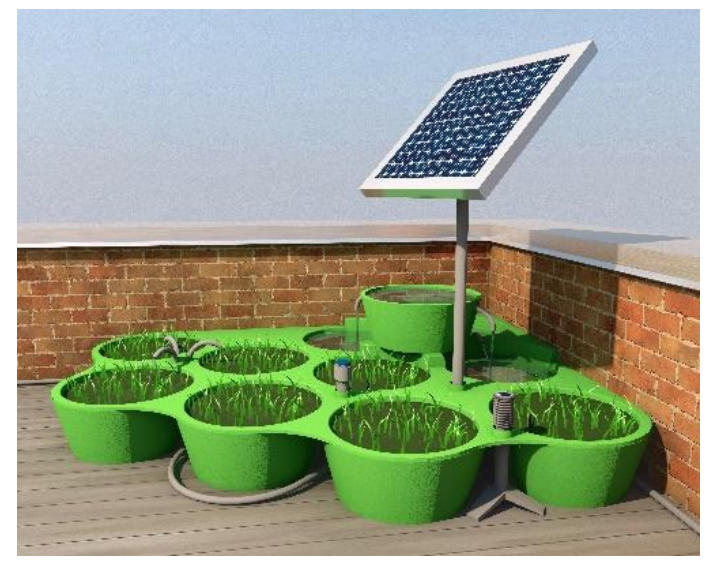

Fig. 2. Modern solution of modular green roof system

The roof is the top cover element (roof), which protects the building from the ingress of precipitation. It includes roofing material, basement under the roof, accessories for ensuring ventilation, adjoining, safe movement and operation, snow retention, etc. In case of the developed roofing system with greening is exploitable, it is equipped with a protective scraper and is designed for people to stay on it, as well as, if necessary, the placement of equipment, vehicles, etc. Modular greening systems have specific structural and technological features that must be taken into account when developing organizational and technological design documents. Decomposition into individual structural elements of the developed constructive solution of the operated roof with modular greening systems made it possible to describe the sequence of their installation in the design position during work on the construction site and to formulate the composition of the relevant technological processes and operations (table 1). 
Table 1. The structural elements and technological processes of modular green roof system

\begin{tabular}{|c|c|}
\hline Structural elements & Technological processes and operations \\
\hline \multicolumn{2}{|l|}{ I. Support structure } \\
\hline 1.Base coating (reinforced concrete slab) & I. Support structure \\
\hline & 1.1 Installation of formwork \\
\hline II. Multilayer construction & 1.2. Plate Reinforcement \\
\hline 2. Vapor barrier & 1.3. Concreting slabs \\
\hline 3. Thermal insulation layer & 1.4. Formwork \\
\hline 4. Waterproofing layer & \\
\hline 5. Adjustable support & II. Multilayer construction \\
\hline 6. Slatted flooring & 2.1. Vapor barrier \\
\hline & 2.2. Thermal insulation device \\
\hline III. Roof & 2.3. Waterproofing device \\
\hline 7.Module (round tray made of HDPE material) & 2.4. Adjustable support device \\
\hline $\begin{array}{l}\text { 8. Drip irrigation tubes (irrigation system } \\
\text { integration) }\end{array}$ & 2.5. Laying the grating \\
\hline 9. Geotextile bag & III. Roof \\
\hline 10. The soil layer & 3.1 Installing soil and vegetation modules \\
\hline 11. The layer is vegetable. & \\
\hline
\end{tabular}

On the basis of the formation of scientifically sound rational technological parameters and methods of organizing and carrying out work, there is an increase in the manufacturability of the construction of exploited roofing with greening systems.

\section{Results and discussion}

As the results of streamlining the technological processes and operations of the roofing device with modular greening systems, the organizational and technological sequence of the roofing device with the modular greening system is formed.

We have established the main organizational and technological parameters, such as labor costs, duration of work, qualifications of performers and mechanization facilities of the works.

Organizational and technological stages of the forensic construction and technical expert examination have been investigated $[7,8]$. The organizational of construction as a complex of works in the implementation of high-rise buildings were studied [9-12]. The innovative and technical solutions for environmental sustainability in the construction, which were described in this article were also considered $[13,14]$. 


\begin{tabular}{|c|c|c|c|c|c|c|c|c|c|c|c|c|c|}
\hline \multirow{2}{*}{ Technological Processes and operations } & \multicolumn{13}{|c|}{ Working time, min } \\
\hline & 10 & 20 & 30 & 40 & 50 & 60 & 70 & 80 & 90 & 100 & 110 & 120 & 130 \\
\hline \multicolumn{14}{|l|}{$\begin{array}{l}\text { Installation of adjustable supports with } \\
\text { a pitch of not more than } 1 \mathrm{~m}\end{array}$} \\
\hline Coating Layout & \multicolumn{2}{|c|}{20} & & & & & & & & & & & \\
\hline Layout and gluing supports & & \multicolumn{2}{|c|}{22} & & & & & & & & & & \\
\hline Adjustment of a tilt angle of a support & & & \multicolumn{4}{|c|}{40} & & & & & & & \\
\hline Fixing special clips & & & & & & \multicolumn{2}{|c|}{14} & & & & & & \\
\hline \multicolumn{14}{|l|}{ Installation of $1 \times 1 \mathrm{~m}$ flooring grid } \\
\hline Laying floor grating on supports & & & & & & & \multicolumn{2}{|c|}{25} & & & & & \\
\hline Fixing the grating & & & & & & & & \multicolumn{2}{|c|}{17} & & & & \\
\hline \multicolumn{14}{|l|}{ Installation of modules for greening } \\
\hline $\begin{array}{l}\text { Installation and connection of a group of } \\
\text { modules in the amount of } 4 \text { units }\end{array}$ & & & & & & & & & \multicolumn{2}{|c|}{22} & & & \\
\hline $\begin{array}{l}\text { Fixing a group of modules to the flooring } \\
\text { grid }\end{array}$ & & & & & & & & & & \multicolumn{2}{|c|}{20} & & \\
\hline \multirow[t]{5}{*}{$\begin{array}{l}\text { Filling a group of modules with planting } \\
\text { material }\end{array}$} & & & & & & & & & & & & 30 & \\
\hline & \multicolumn{13}{|c|}{ The schedule of distribution of labor resources - workers (W) } \\
\hline & W1 & W1 & W1 & W1 & W1 & W1 & W1 & W1 & W1 & W1 & W1 & W1 & $\overline{W 1}$ \\
\hline & W2 & W2 & W2 & W2 & W2 & W2 & W2 & W2 & W2 & W2 & W2 & W2 & W2 \\
\hline & W3 & W3 & W3 & W3 & W3 & W3 & W3 & W3 & W3 & W3 & W3 & W3 & W3 \\
\hline
\end{tabular}

Fig. 3. The organizational and technological sequence of the modular green roof system

\section{Conclusion}

Application of the approaches of organizational-technological modeling in the construction of buildings with green roofs will allow verification with a limited set of experimental data. The organizational and technological model of the modular green roof system was built, rational parameters of technological processes and operations were established. This research stimulates development of the mechanism of attracting investments in modernization of public utility facilities, considering all possible risks in the Russian construction industry [15-20].

The effectiveness of the implementation of organizational and technological measures and innovative technologies on roofing, the placement of new technological equipment, means of mechanization and other opportunities for improving the comfort conditions of construction objects is considered. However, the current regulatory and technical base does not regulate the technology of roofing with green plantings and does not allow to verify the technological parameters of the work and evaluate the required quality of their implementation. Technological processes for the installation of roofing with modular greening systems are characterized by the best indicators of the complexity of the work. Based on the study, the results obtained can be the basis for the development of technological regulations and a technological map for the implementation of new technology for the installation of operating roofing with greening systems. 


\section{References}

1. D.A. Vandegrift, D.B. Rowe, B. M. Cregg, D. Liang. Ecological Engineering, 138, 264-273 (2019) https://doi.org/10.1016/j.ecoleng.2019.07.032

2. M. Ramshani, X. Li, A. Khojandi, O. Omitaomu. Applied Energy, 261, 114402 (2020) https://doi.org/10.1016/j.apenergy.2019.114402

3. Y. He, H. Yu, P. Chen, M. Zhao. Energy Procedia, 152, 384-389 (2018) https://doi.org/10.1016/j.egypro.2018.09.161

4. Y. Gong, D. Yin, J. Li, X. Zhang, Q. Wang. Science of The Total Environment, 687, 505-515 (2019) https://doi.org/10.1016/j.scitotenv.2019.06.100

5. N.J. Paull, P.J. Irga, F.R. Torpy, Environmental Pollution, 240, 448-456 (2018) https://doi.org/10.1016/j.envpol.2018.05.004

6. B. Chak-Man Leung, Energy Reports, 4, 159-206 (2018) https://doi.org/10.1016/j.egyr.2018.01.003

7. I. Y. Zilberova, V. D. Mailyan, A. L. Mailyan, IOP Conference Series: Materials Science and Engineering. 698, 022085. (2019) 10.1088/1757-899X/698/2/022085.

8. L. Mailyan, A. Chepurnenko, A. Ivanov, 2016 Procedia Engineering, 165, 1853-1857 (2016) DOI: 10.1016/j.proeng.2016.11.933

9. P. Oleynik, S. Sinenko, B. Zhadanovsky, V.Brodsky, M. Kuzhin, MATEC Web Conf., 86, 04059 (2016) DOI: https://doi.org/10.1051/matecconf/20168604059

10. M.A. Othuman Mydin, N. Md Sani, M. Taib, and N. Mohd Alias, MATEC Web of Conferences, 10, 06005 (2014). doi:10.1051/matecconf/20141006005

11. P. Kagan, MATEC Web Conf., 170, 01071 (2018) DOI: https://doi.org/10.1051/matecconf/201817001071

12. O. Korol, Y. Kustikova, E3S Web of Conferences, 33, 03070, (2018), DOI: $10.1051 / \mathrm{e} 3$ sconf $/ 20183303070$

13. O. Korol, P. Kagan, Innovative and technical solutions for environmental sustainability in the construction and management of urban housing and communal services. 100-107 (2014)

14. E. Korol, I. Kiselev, N. Shushunova News of higher educational institutions. $\begin{array}{llllll}\text { Technology textile industry } & 3 & \text { (375) } & 294-300 & \text { (2018) }\end{array}$ http://ttp.ivgpu.com/wpcontent/uploads/2018/10/375_59.pdf(In Russian)

15. V. Teplyshev, R. Petrosyan, D. Spitsov, V. Smirnov and M. Pushkareva, MATEC Web Conf., 193, 05079 (2018) DOI: https://doi.org/10.1051/matecconf/201819305079

16. V. Kankhva, B. Orlov, A. Vorobyeva, S. Belyaeva and R. Petrosyan, MATEC Web Conf., 17001116 (2018), DOI: https://doi.org/10.1051/matecconf/201817001116

17. M.Kh. Kangezova, R.S. Petrosyan, R.A. Zherugov, Science and business: development ways, 6(96) (2019)

18. V.G. Borkovskaya Applied Mechanics and Materials, 475-476. 1703-1706 (2013). DOI: 10.4028/www.scientific.net/AMM.475-476.1703

19. V.G. Borkovskaya, W. Bardenwerper, R. Roe, IOP Conf. Series: Materials Science and Engineering, 365, 062030 (2018) doi:10.1088/1757-899X/365/6/062030

20. V.G., Borkovskaya E. Degaev, I. Burkova MATEC Web of Conf., 193, 05027 (2018) DOI: https://doi.org/10.1051/matecconf/201819305027. 